\title{
Evaluation of semen quality among four chicken lines
}

\author{
Abu Md. Mamun Tarif ${ }^{1}$ Mohammad Musharraf Uddin Bhuiyan ${ }^{2}$, \\ Raihana Nasrin Ferdousy ${ }^{3}$, Nasrin Sultana Juyena ${ }^{4}$ and \\ Md. Bazlur Rahman Mollah ${ }^{5}$ \\ ${ }^{1}$ Department of surgery and obstetrics, Bangladesh Agricultural University, Bangladesh) \\ ${ }^{2}$ (Department of surgery and obstetrics, Bangladesh Agricultural University, Bangladesh) \\ 3 (Department of surgery and obstetrics, Bangladesh Agricultural University, Bangladesh) \\ ${ }^{4}$ (Department of surgery and obstetrics, Bangladesh Agricultural University, Bangladesh) \\ ${ }_{5}^{5}$ (Departtment of poultry science, Bangladesh Agricultural University, Bangladesh)
}

\begin{abstract}
Evaluation of semen quality is very important before selection of breeding cocks used for artificial insemination. The aim of this study was to characterize the semen parameters of 4 lines of cocks followed by comparison of such parameters among lines. A total of 60 semen samples were collected from 3 Sasso, 3 Synthetic and 3 White Rock and 3 Assel RIR cock at 3 days interval. Semen was collected by abdominal massage method. Semen parameters with respect to ejaculate volume, mass activity, sperm motility, sperm concentration, proportion of live spermatozoa and proportion of spermatozoa with normal morphology were examined. The semen parameters did not differ significantly among individual cocks of Sasso line. However, sperm concentration varied significantly among individual cocks of Synthetic, White Rock and Assel RIR lines. The ejaculate volume, mass activity, sperm motility, sperm concentration, proportion of live spermatozoa and proportion of spermatozoa with normal morphology varied from $410.0 \pm 0.0$ to $810.0 \pm 0.0 \mu l, 3.8 \pm 0.1$ to $4.0 \pm$ $0.0+, 71.1 \pm 1.1$ to $83.3 \pm 1.2 \%, 7.5 \pm 0.1$ to $9.6 \pm 0.2 \times 10^{9} / \mathrm{ml}, 82.2 \pm 1.3$ to $87.3 \pm 1.1 \%$ and $87.2 \pm 0.8$ to 90.1 $\pm 0.7 \%$, respectively. However, only the variations in ejaculate volume, sperm motility, sperm concentration and proportion of live spermatozoa were significant among lines of cocks $(P<0.05)$. It is concluded that semen quality of different lines of cocks were within normal range although variations in some parameters of semen may exist among lines.
\end{abstract}

Keywords: artificial insemination, chicken Lines, concentration, morphology, motility

\section{INTRODUCTION}

During the last decade, poultry industry in Bangladesh had exponential growth. Its growth rate is about 20\%. In 2011-12, total population of chicken and egg production in Bangladesh was 242.866 million and 7303.89 million respectively [1]. About 5 million people are directly or indirectly involved with poultry industry and approximately $50 \%$ of them are women. A large section of the marginalized rural people earns their living through this industry. Commercial and small scale poultry production units contribute in supplying local people with additional income and a supply of high quality protein for the household. However, problems with disease, breeding, nutrition and marketing are the major constraints against development of this sector.For genetic improvement, artificial insemination (AI) is regarded as an important breeding tool throughout the world. Like other livestock species, assessment of semen quality before being used for AI in poultry is essential. Because, like other species, quality of semen after processing may significantly affect the success of AI in poultry.Fertilizing ability of spermatozoa can be evaluated by examination of sperm motility, number of spermatozoa per dose of semen and proportion of morphologically normal spermatozoa in it [2]. Moreover, volume and color of semen sample are also evaluated to determine the teasing of male and presence of any lesion or infection in genital tract. In addition to hereditary traits, quality of semen may vary with breed and strain, age, body weight of cocks, collection technique and diluents used. Many researchers have worked on semen production and quality on a variety of poultry breeds and strains [3],[4],[5],[6]. The semen collector can affect semen quality by contamination of semen with feces, urine and blood which can be detected by evaluation of color of semen[7]. Sometimes, dilution of chicken semen may result in a significant decrease in the percentage of dead sperm in stored semen. Sperm motility from both undiluted and diluted chicken semen was the lowest when stored at $41^{\circ} \mathrm{C}$ compared to storage at 25,15 or $5^{\circ} \mathrm{C}$ [8]. Moreover, there are reports that breed and seasonal differences may affect semen production of cocks [9]. However, contrasting report showed that breed and time of semen collection affected the production of cock semen elsewhere [10]. However, there is very limited study on evaluation of semen quality of poultry in Bangladesh [11]. Therefore, it seems rational to determine the line related variation in quality of semen before being used for routine AI in poultry. The present investigation was conducted to characterize the parameters of fresh semen of four different chicken lines and to compare the quality of semen among four different chicken lines. 


\subsection{Study area and period}

\section{Materials And Methods}

The experiment was conducted at the Community-based Dairy Veterinary Foundation (CDVF) Laboratory, Department of Surgery and Obstetrics and the Poultry Farm, Bangladesh Agricultural University, Mymensingh during the period from January to May, 2013.

\subsection{Experimental cocks}

Three cocks from each of 4 different 4 th generation lines (total 12 cocks) that have been developed by selective line breeding namely Sasso, Synthetic, White Rock and Assel RIR as shown in figure 1A, 1B, $1 \mathrm{C}, 1 \mathrm{D}$ were selected as semen donors for this experiment. The cocks of all lines were 40 weeks old. The body weight of Sasso cocks was 3.0 to $3.5 \mathrm{~kg}$, Synthetic cocks was 5.0 to $5.5 \mathrm{~kg}$, White Rock cocks was 2.0 to $3.5 \mathrm{~kg}$ and Assel RIR cocks was 2.2 to $2.5 \mathrm{~kg}$. The selected cocks were matured, aparently healthy and free from any physical defects.
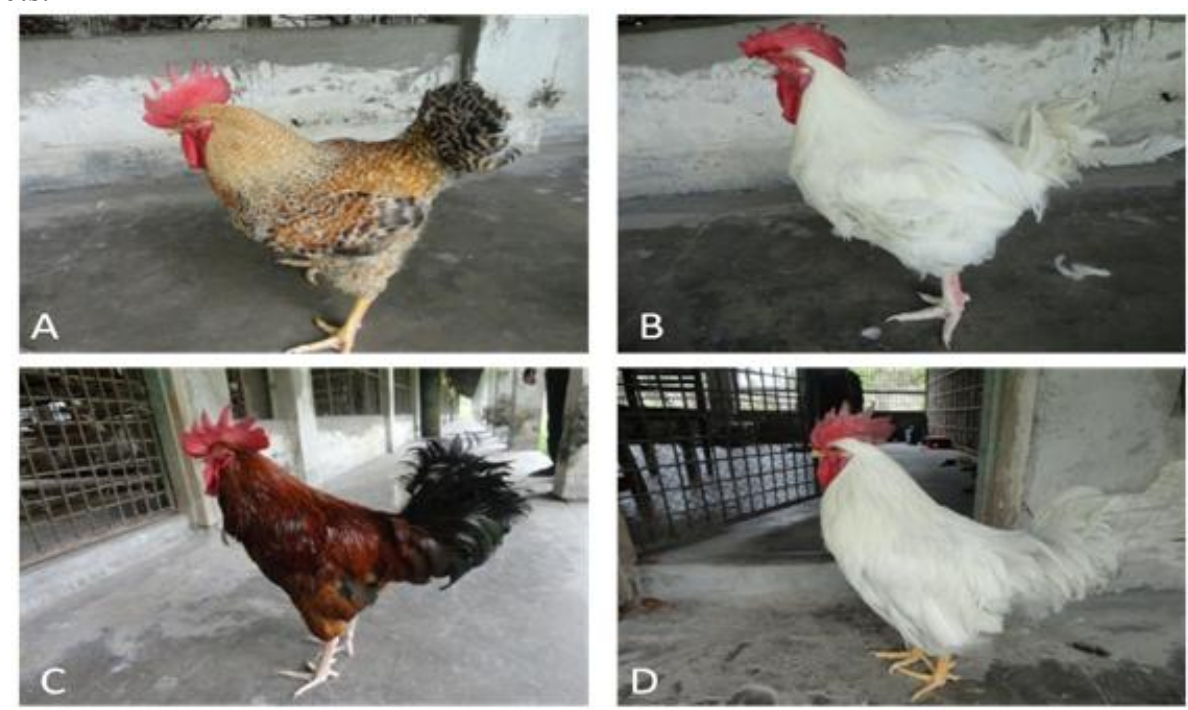

Fig.1 Images of experimental cocks. (A) Sasso, (B) Synthetic,(C) Assel RIR, (D) White Rock

\subsection{Housing and feeding of the cocks}

The cocks were managed intensively in a battery cage system and each cock was kept in an individual cage $(52 \times 45 \times 38 \mathrm{~cm})$. All males received $16 \mathrm{~h}$ light/day throughout the experiment. Each cock was fed daily with 110-160 gram nourish layer commercial feed of Nourish poultry feed at 40 weeks age.

\subsection{Semen collection}

The cocks were allowed a week of adaptation prior to the onset of semen collection and were trained to respond to the abdominal massage technique prior to semen. Single ejaculate of semen was collected from each cock twice a week between 9:00 and 11:00 AM by abdominal massage method. Five replicates of semen samples were collected from each of 12 cocks across the days. Semen collection and evaluation was performed at room temperature.

\subsection{Semen evaluation}

The ejaculate volume and color of semen were macroscopically evaluated immediately after collection and recorded directly from the semen collection tube. The volume of semen was expressed as microlitre $(\mu 1)$.

To evaluate mass activity, a drop of undiluted semen was placed on a slide without cover slip and examined under compound microscope (100x) and scored into 1-5 scales $(1+=$ no perceptible motion, $2+=$ few spermatozoa move without forming any waves, $3+=$ small slow moving waves, $4+=$ vigorous movement with moderately rapid wave and eddies and $5+=$ dense,rapidly moving waves and eddies). Semen was then diluted 1:100 (semen: extender) using modified Ringer's solution (sodium chloride: $68 \mathrm{~g}$, potassium chloride: $17.33 \mathrm{~g}$, calcium chloride: $6.42 \mathrm{~g}$, magnesium sulphate: $2.5 \mathrm{~g}$, sodium bicarbonate: $24.5 \mathrm{~g}$, distilled water: $1000 \mathrm{ml}$ ) according to[12].For evaluation of motility, one drop of the diluted semen was placed on the slide and covered with glass cover slip. The sperm motility was estimated by microscopic observation at 400x magnification. Motility was expressed as the percentage of motile spermatozoa with moderate to rapid progressive movement. At least 3 microscopic fields were examined for each sample. 
The sperm concentration of an ejaculate was determined by using a hemocytometer chamber after dilution with distilled water at 1:400 ratio and expressed as billion $\left(10^{9}\right)$ per ml.To determine the percentage of live sperm, eosin-nigrosin stain was used. The stain was prepared by dissolving $1.67 \mathrm{~g}$ of eosin, $10 \mathrm{~g}$ nigrosin (water soluble) and $2.9 \mathrm{~g}$ sodium citrate with two molecules $\mathrm{H}_{2} \mathrm{O}$ in $100 \mathrm{ml}$ distilled water [13]. The stain was filtered before use. Briefly, a $10 \mu \mathrm{l}$ drop of fresh semen was mixed with $200 \mu \mathrm{l}$ of eosin-nigrosin stain on a glass slide followed by making a thin smear of it.

The spermatozoa were examined at 400x magnification under a phase contrast microscope. At least 100 spermatozoa were counted to determine the percentage of live sperm spermatozoa. The spermatozoa which were appeared with pink color (stained with eosin) were regarded as dead as shown in figure 2and spermatozoa which were appeared without any color (no penetration of eosin stain) were regarded as live.

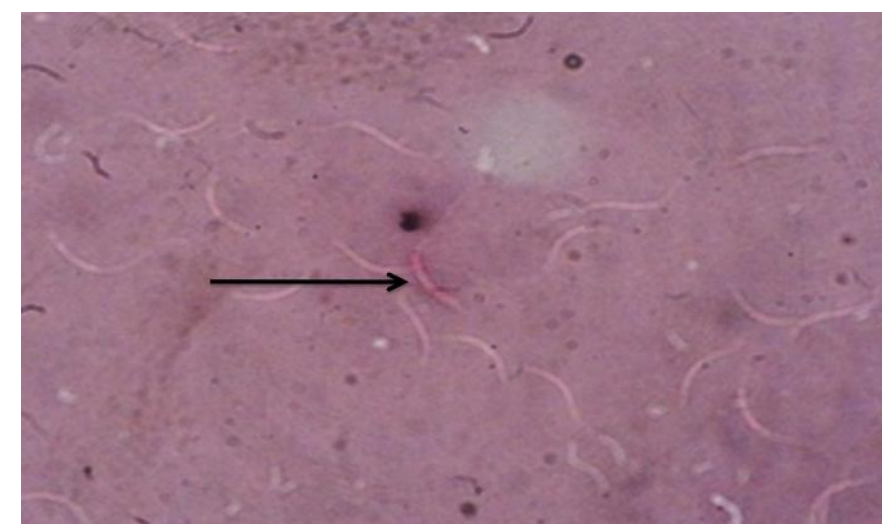

Fig.2 Photomicrography of cock spermatozoa, pink color (stained with eosin) regarded as dead and without any color (no penetration of eosin stain) regarded as live (Eosin Nigrosin Stain, 400)

The abnormalities of the head, mid-piece and tail of the spermatozoa were evaluated in formol salinefixed spermatozoa using phrase contrast optics at 1000x magnification (Figure 8). The buffered formol saline was prepared by dissolving $34.7 \mathrm{mmol}$ disodium hydrogen phosphate with two molecules $\mathrm{H}_{2} \mathrm{O}, 18.7 \mathrm{mmol}$ potassium dihydrogen phosphate, $92.6 \mathrm{mmol}$ sodium chloride and1.54 mol formaldehyde in $1000 \mathrm{ml}$ distilled water [14]. At least 200 spermatozoa were examined from each sample.

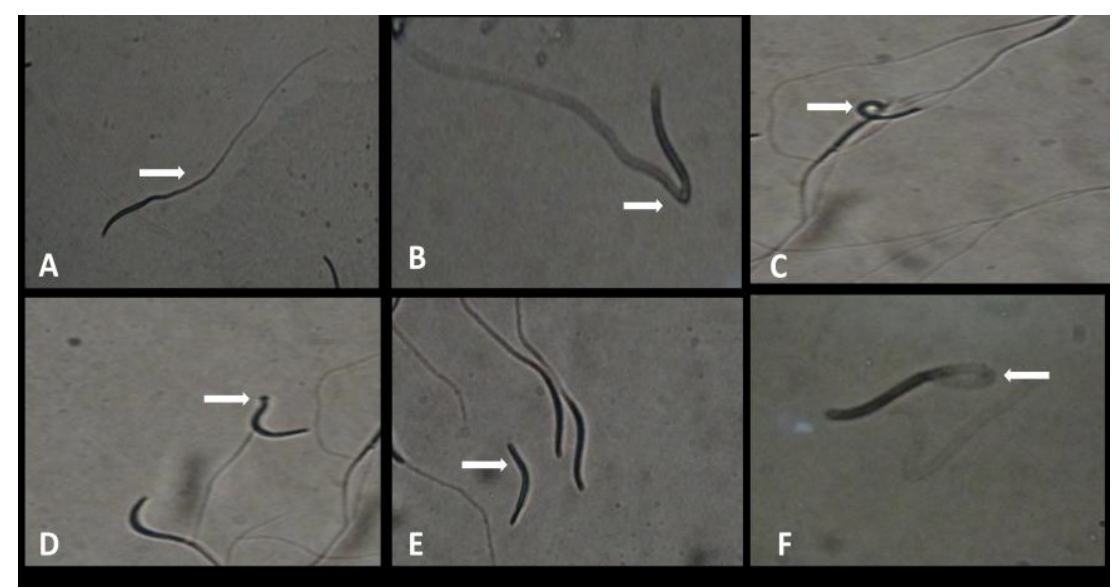

Fig.3 Photomicrography of normal and abnormal morphology of cock spermatozoa (Formol Saline, 1000X with emersion oil) (A) Morphologically normal, (B) Simple bent at the mid piece, (C) Coiled head, (D) Broken tail,(E)Loose head, (F) Tail coiled below the head of the spermatozoa.

\subsection{Statistical Analyses}

Data were analyzed by using statistical program (SPSS, version 17). One way analysis of variance (ANOVA) was done to find out significant difference among different level of lines of cocks. Pair t-test was done to find the differences in semen quality with respect to volume, mass activity, motility, concentration, viability and morphological defects among four lines of cocks. The data were presented as Mean \pm SEM. The variations in parameters among individual cocks and line of cocks were regarded as significant when the $\mathrm{P}$ value was $<0.05$. 


\section{Results And Discussion}

The present study was carried out to characterize the parameters of fresh semen of four different chicken breeds and to compare the quality of semen among four different chicken lines. In Sasso line cocks, ejaculate volume, mass activity, sperm motility, sperm concentration, proportion of live spermatozoa and proportion of spermatozoa with normal morphology were $770.0 \pm 0.0$ to $800.0 \pm 0.1 \mu 1,4.0 \pm 0.0+, 81.7 \pm 1.7$ to $85.0 \pm 2.9 \%, 9.2 \pm 0.3$ to $9.9 \pm 0.3 \times 10 \% / \mathrm{ml}, 84.7 \pm 1.9$ to $89.0 \pm 1.5 \%$ and $89.7 \pm 1.9$ to $90.3 \pm 1.2 \%$, respectively as shown in table 1 . There was no significant variation in semen parameters among individual cocks of Sasso line.

Table 1: Data on semen parameters of cocks of Sasso line

\begin{tabular}{|l|l|l|l|l|l|l|}
\hline Line & $\begin{array}{l}\text { Ejaculate } \\
\text { volume } \\
(\mu 1)\end{array}$ & $\begin{array}{l}\text { Mass } \\
\text { activity } \\
(+)\end{array}$ & $\begin{array}{l}\text { Sperm } \\
\text { motility } \\
(\boldsymbol{\%})\end{array}$ & $\begin{array}{l}\text { Sperm } \\
\text { concentration } \\
(\mathbf{n} \times \mathbf{1 0}) / \mathbf{m l}\end{array}$ & $\begin{array}{l}\text { Live sperm } \\
(\boldsymbol{\%})\end{array}$ & $\begin{array}{l}\text { Normal } \\
\text { spermatozoa }(\boldsymbol{\%})\end{array}$ \\
\hline Sasso 1 & $770.0 \pm 0.0$ & $4.0 \pm 0.0$ & $81.7 \pm 1.7$ & $9.8 \pm 1.7$ & $88.3 \pm 1.8$ & $89.7 \pm 1.9$ \\
\hline Sasso 2 & $800.0 \pm 0.1$ & $4.0 \pm 0.0$ & $85.0 \pm 2.9$ & $9.2 \pm 0.3$ & $89.0 \pm 1.5$ & $90.3 \pm 1.2$ \\
\hline Sasso 3 & $770.0 \pm 0.0$ & $4.0 \pm 0.0$ & $83.3 \pm 1.7$ & $9.9 \pm 0.3$ & $84.7 \pm 1.9$ & $90.3 \pm 0.9$ \\
\hline
\end{tabular}

Values are mean \pm SEM.

Values within same column did not differ significant from each other $(\mathrm{P}>0.05)$.

In Synthetic line cocks, ejaculate volume, mass activity, sperm motility, sperm concentration, proportion of live spermatozoa and proportion of spermatozoa with normal morphology were $530.0 \pm 0.0$ to $670.0 \pm .0 \mu \mathrm{l}, 4.0 \pm 0.0+, 73.0 \pm 1.7$ to $78.0 \pm 1.7 \%, 8.6 \pm 0.3$ to $9.5 \pm 0.2 \times 10 \% / \mathrm{ml}, 86.0 \pm 1.2$ to $88.0 \pm 1.2 \%$ and $88.7 \pm 0.7$ to $89.7 \pm 0.9 \%$, respectively as shown in table 2 . There was no significant variation in semen parameters among individual cocks of Synthetic line except sperm concentration $(\mathrm{P}<0.05$ for sperm concentration).

Table 2: Data on semen parameters of cocks of Synthetic line

\begin{tabular}{|l|l|l|l|l|l|l|}
\hline Line & $\begin{array}{l}\text { Ejaculate } \\
\text { volume } \\
(\mu \mathrm{l})\end{array}$ & $\begin{array}{l}\text { Mass } \\
\text { activity } \\
(+)\end{array}$ & $\begin{array}{l}\text { Sperm } \\
\text { motility } \\
(\boldsymbol{\%})\end{array}$ & $\begin{array}{l}\text { Sperm } \\
\text { concentration } \\
\left(\mathbf{n} \times \mathbf{1 0}^{\mathbf{9}}\right) / \mathbf{m l}\end{array}$ & $\begin{array}{l}\text { Live } \\
\text { sperm } \\
(\boldsymbol{\%})\end{array}$ & $\begin{array}{l}\text { Normal } \\
\text { spermato-zoa } \\
(\boldsymbol{\%})\end{array}$ \\
\hline Synthetic 1 & $530.0 \pm 0.0$ & $4.0 \pm 0.0$ & $78.3 \pm 1.7$ & $9.5 \pm 0.2^{\mathrm{a}}$ & $86.0 \pm 1.2$ & $88.7 \pm 0.7$ \\
\hline Synthetic 2 & $670.0 \pm 0.0$ & $4.0 \pm 0.0$ & $73.3 \pm 1.7$ & $8.9 \pm 0.1^{\mathrm{b}}$ & $88.0 \pm 1.2$ & $89.7 \pm 0.9$ \\
\hline Synthetic 3 & $630.0 \pm 0.0$ & $4.0 \pm 0.0$ & $78.3 \pm 1.7$ & $8.6 \pm 0.3^{\mathrm{b}}$ & $87.7 \pm 1.9$ & $89.0 \pm 1.0$ \\
\hline
\end{tabular}

Values are mean \pm SEM.

${ }^{\mathrm{a}, \mathrm{b}}$ Values with superscript within same column differed significant from each other $(\mathrm{P}<0.05)$.

In White Rock line cocks, ejaculate volume, mass activity, sperm motility, sperm concentration, proportion of live spermatozoa and proportion of spermatozoa with normal morphology were $470.0 \pm 0.0$ to $500.0 \pm 0.0 \mu \mathrm{l}, 3.7 \pm 0.3$ to $4.0 \pm 0.0+, 78.3 \pm 1.7$ to $78.3 \pm 3.3 \%, 7.7 \pm 0.2$ to $8.9 \pm 0.3 \times 10^{9} / \mathrm{ml}, 80.7 \pm 2.9$ to $84.0 \pm 2.3 \%$ and $85.7 \pm 1.5$ to $89.0 \pm 0.6 \%$, respectively as shown in table 3 . There was no significant variation in semen parameters among individual cocks of White Rock line except sperm concentration $(\mathrm{P}<0.05$ for sperm concentration).

Table 3:Data on semen parameters of cocks of White Rock line

\begin{tabular}{|l|l|l|l|l|l|l|}
\hline Line & $\begin{array}{l}\text { Ejaculate } \\
\text { volume } \\
(\mu \mathrm{l})\end{array}$ & $\begin{array}{l}\text { Mass } \\
\text { activity } \\
(+)\end{array}$ & $\begin{array}{l}\text { Sperm } \\
\text { motility } \\
(\mathbf{\%})\end{array}$ & $\begin{array}{l}\text { Sperm } \\
\text { concentration } \\
\left(\mathbf{n} \times \mathbf{1 0}^{\mathbf{9}}\right) / \mathbf{m l}\end{array}$ & $\begin{array}{l}\text { Live } \\
\text { sperm } \\
(\mathbf{\%})\end{array}$ & $\begin{array}{l}\text { Normal } \\
\text { spermatozoa (\%) }\end{array}$ \\
\hline $\begin{array}{l}\text { White } \\
\text { Rock 1 }\end{array}$ & $500.0 \pm 0.0$ & $4.0 \pm 0.0$ & $78.3 \pm 3.3$ & $7.9 \pm 0.2^{\mathrm{b}}$ & $84.0 \pm 2.3$ & $87.0 \pm 1.5$ \\
\hline $\begin{array}{l}\text { White } \\
\text { Rock 2 }\end{array}$ & $470.0 \pm 0.0$ & $4.0 \pm 0.0$ & $78.3 \pm 1.7$ & $8.9 \pm 0.3^{\mathrm{a}}$ & $82.0 \pm 2.1$ & $85.7 \pm 1.5$ \\
\hline $\begin{array}{l}\text { White } \\
\text { Rock 3 }\end{array}$ & $470.0 \pm 0.0$ & $3.7 \pm 0.3$ & $78.3 \pm 1.7$ & $7.7 \pm 0.2^{\mathrm{b}}$ & $80.7 \pm 2.9$ & $89.0 \pm 0.6$ \\
\hline
\end{tabular}

Values are mean \pm SEM.

${ }^{\mathrm{a}, \mathrm{b}}$ Values with superscript within same column differed significant from each other $(\mathrm{P}<0.05)$.

In Assel RIR line cocks, ejaculate volume, mass activity, sperm motility, sperm concentration, proportion of live spermatozoa and proportion of spermatozoa with normal morphology were $330.0 \pm 0.0$ to $470.0 \pm 0.0 \mu \mathrm{l}, 3.7 \pm 0.0$ to $4.0 \pm 0.0+, 70.0 \pm 2.9$ to $71.7 \pm 1.7 \%, 7.8 \pm 0.1$ to $7.3 \pm 0.2 \times 10^{9} / \mathrm{ml}, 80.3 \pm 0.9$ to $86.7 \pm 1.2 \%$ and $87.0 \pm 2.5$ to $90.3 \pm 1.3 \%$, respectively as shown in table 4 . There was no significant variation in semen parameters among individual cocks of Assel RIR line except sperm concentration $(\mathrm{P}<0.05$ for sperm concentration). 
Table 4:Data on semen parameters of cocks of Assel RIR line

\begin{tabular}{|l|l|l|l|l|l|l|}
\hline Line & $\begin{array}{l}\text { Ejaculate } \\
\text { volume } \\
(\mu 1)\end{array}$ & $\begin{array}{l}\text { Mass } \\
\text { activity } \\
(+)\end{array}$ & $\begin{array}{l}\text { Sperm } \\
\text { motility } \\
(\boldsymbol{\%})\end{array}$ & $\begin{array}{l}\text { Sperm } \\
\text { concentration } \\
\left(\mathbf{n} \times \mathbf{1 0}^{\mathbf{9}}\right) / \mathbf{m l}\end{array}$ & $\begin{array}{l}\text { Live } \\
\text { sperm } \\
(\boldsymbol{\%})\end{array}$ & $\begin{array}{l}\text { Normal } \\
\text { spermatozoa (\%) }\end{array}$ \\
\hline $\begin{array}{l}\text { Assel RIR } \\
\mathbf{1}\end{array}$ & $330.0 \pm 0.0$ & $4.0 \pm 0.0$ & $71.7 \pm 1.7$ & $7.8 \pm 0.1^{\mathrm{a}}$ & $83.0 \pm 2.1$ & $87.0 \pm 2.5$ \\
\hline $\begin{array}{l}\text { Assel RIR } \\
\mathbf{2}\end{array}$ & $430.0 \pm 0.0$ & $3.7 \pm 0.0$ & $70.0 \pm 2.9$ & $7.3 \pm 0.1^{\mathrm{b}}$ & $80.3 \pm 0.9$ & $88.7 \pm 1.5$ \\
\hline $\begin{array}{l}\text { Assel RIR } \\
\mathbf{3}\end{array}$ & $470.0 \pm 0.0$ & $3.7 \pm 0.0$ & $71.7 \pm 1.7$ & $7.3 \pm 0.2^{\mathrm{b}}$ & $86.7 \pm 1.2$ & $90.3 \pm 1.3$ \\
\hline
\end{tabular}

Values are mean \pm SEM.

a,b,c,d Values with superscript within same column differed significant from each other $(\mathrm{P}<0.05)$.

The ejaculate volume, mass activity, sperm motility, sperm concentration, proportion of live spermatozoa and proportion of spermatozoa with normal morphology varied from $410.0 \pm 0.0$ to $810.0 \pm 0.0 \mu 1$, $3.8 \pm 0.1$ to $4.0 \pm 0.0+, 71.1 \pm 1.1$ to $83.3 \pm 1.2 \%, 7.5 \pm 0.1$ to $9.6 \pm 0.2 \times 10^{9} / \mathrm{ml}, 82.2 \pm 1.3$ to $87.3 \pm 1.1 \%$ and $87.2 \pm 0.8$ to $90.1 \pm 0.7 \%$, respectively as shown in table 5 . However, only the variations in ejaculate volume, sperm motility, sperm concentration and proportion of live spermatozoa among lines of cocks were significant $(\mathrm{P}<0.05)$.

Table 5: Comparison of semen parameters among cocks of 4 lines

\begin{tabular}{|l|l|l|l|l|l|l|}
\hline Line & $\begin{array}{l}\text { Ejaculate } \\
\text { volume } \\
(\mu 1)\end{array}$ & $\begin{array}{l}\text { Mass } \\
\text { activity } \\
(+)\end{array}$ & $\begin{array}{l}\text { Sperm } \\
\text { motility } \\
(\boldsymbol{\%})\end{array}$ & $\begin{array}{l}\text { Sperm } \\
\text { concentration } \\
\left(\mathbf{n} \times \mathbf{1 0}^{\mathbf{9}}\right) / \mathbf{m l}\end{array}$ & $\begin{array}{l}\text { Live } \\
\text { sperm } \\
(\boldsymbol{\%})\end{array}$ & $\begin{array}{l}\text { Normal } \\
\text { spermatozoa } \\
(\boldsymbol{\%})\end{array}$ \\
\hline Sasso & $780.0 \pm 0.0^{\mathrm{b}}$ & $4.0 \pm 0.0$ & $83.3 \pm 1.2^{\mathrm{a}}$ & $9.6 \pm 0.2^{\mathrm{a}}$ & $87.3 \pm 1.1^{\mathrm{a}}$ & $90.1 \pm 0.7$ \\
\hline Synthetic & $810.0 \pm 0.0^{\mathrm{a}}$ & $4.0 \pm 0.0$ & $76.7 \pm 1.2^{\mathrm{b}}$ & $9.0 \pm 0.2^{\mathrm{b}}$ & $87.2 \pm 0.8^{\mathrm{a}}$ & $89.1 \pm 0.5$ \\
\hline White rock & $470.0 \pm 0.0^{\mathrm{c}}$ & $3.9 \pm 0.1$ & $78.3 \pm 1.2^{\mathrm{b}}$ & $8.2 \pm 0.2^{\mathrm{c}}$ & $82.2 \pm 1.3^{\mathrm{b}}$ & $87.2 \pm 0.8$ \\
\hline Assel RIR & $410.0 \pm 0.0^{\mathrm{c}}$ & $3.8 \pm 0.1$ & $71.1 \pm 1.1^{\mathrm{c}}$ & $7.5 \pm 0.1^{\mathrm{d}}$ & $83.3 \pm 1.2^{\mathrm{b}}$ & $88.7 \pm 1.0$ \\
\hline
\end{tabular}

Values are mean \pm SEM.

a,b,c,d Values with superscript within same column differed significant from each other $(\mathrm{P}<0.05)$.

In the present study, semen parameters with respect to ejaculate volume, mass activity, sperm motility, sperm concentration, proportion of live spermatozoa and proportion of spermatozoa with normal morphology did not differ significantly among individual cocks of Sasso line. However, sperm concentration varied significantly among individual cocks although no variation was obtained in other semen parameters among individual cocks of Synthetic, White Rock and Assel RIR lines.

In the present study, the semen volume differed significantly among lines of cocks. The reason for variation in semen volume among lines may be explained by the fact that utilization of diets, management, normal physiological processes regulating spermatogenesis and respond to the massage technique during semen collection might vary among lines [15]. Usually utilization of diet by cocks is indicated by rapid gain of body weight which may also influence the semen production in cocks. In the present study, the body weight of 4 lines of cocks varied from $2.3 \mathrm{~kg}$ (Assel RIR line) to $5.3 \mathrm{~kg}$ (Synthetic line) and the obtained semen volume positively correlated with increasing body weight of cocks. The positive correlation between body weight of cocks and semen volume has also been demonstrated elsewhere [16].Generally, poultry lines with heavier body weights and larger testes produce more spermatozoa during spermatogenesis and thus may yield bigger semen volume [17]. Nevertheless, contrasting to the present study, lower semen volume of native cocks was reported in Bangladesh [11] and in Nigeraia [4]. However, similar volume of cock semen was obtained in Denizli cocks by [18] and in Nigerian indigenous cocks by [6]. The reason for variation in semen volume among studies may be due to variation in lines studied and agro-climatic condition of countries where experiment was conducted.

In the present study, sperm motility significantly varied among line of cocks. The motility of cock spermatozoa was found $71.1 \%$ to $83.3 \%$ in four lines of cock in this study and sperm motility was significantly higher in Sasso line than other lines. Similar sperm motility in fresh semen of cocks (73.9 to 83.2\%) has been observed in earlier studies [19], [4].Contrasting to the present finding, reference [20] reported lower (67.9 to $70.1 \%$ ) motility of fresh semen of cocks elsewhere. Additionally, other researchers found $83.2 \%$ sperm motility in White Leghorn line and $77.6 \%$ in New Hampshire cocks [19],[18]. There are several factors affecting sperm motility following semen dilution. Avian sperm motility may be affected by the amount of oxygen and Ca++ ions present in semen [21]. The reason for variation in semen motility among lines may be explained by the fact that the genetic potential of individual line might contribute to this.

In the present study, sperm concentration significantly varied among line of cocks. In this study the sperm concentration varied from $9.6 \times 10^{9}$ to $7.5 \times 10^{9}$ per ml. Contrasting to the present finding, the concentration of spermatozoa in semen of White Rock roosters was $3.5 \times 10^{9} / \mathrm{ml}$ [22].Moreover, Hafez and Hafez (2000) demonstrated that the sperm concentration in domestic cock might range from 3 to $7 \times 10^{9} / \mathrm{ml}$. Further, a sperm concentration of 3.8 to $7.5 \times 10^{9} / \mathrm{ml}$ of cock semen has been reported elsewhere [23]. Additionally, a sperm 
concentrations of $2.42 \times 10^{9} / \mathrm{ml}$ was reported in Gerze breed by [18] while other researchers quoted sperm concentrations of $3.53 \times 10^{9} / \mathrm{ml}$ for White Leghorn cocks and $3.347 \times 10^{9} / \mathrm{ml}$ for the New Hampshire breeds [18], [6]. [4] also reported a sperm concentration of $2.26 \times 10^{9} / \mathrm{ml}$ for local indigenous cockerels in Nigeria. The difference in the semen concentration among lines may be attributed to several factors such as generation, genetic variation, individual performance and stimulation.

In the present study, proportion of live spermatozoa significantly varied among line of cocks. The proportion of live spermatozoa in semen sample varied from 82.2 to $87.3 \%$ in this study. Contrasting to the present finding, lower proportion of live spermatozoa (72 to $82 \%$ ) in cock semen has been reported by [24]and higher proportion ( 82 to $89 \%$ ) of live spermatozoa has been reported by [25] elsewhere. The variation in proportion of live spermatozoa among line in the present study may be due to genetic variations in tolerance to diluents used for preservation. Nevertheless, the proportion of live spermatozoa in the present study was good enough for routine $\mathrm{AI}$ in poultry.

In the present study, morphologically normal spermatozoa did not differ significantly among line of cocks and the proportion of morphologically normal in cock semen varied from 87.2to 90.1\%. Similarly[26] reported 91 to $94 \%$ morphologically normal spermatozoa in cock semen. Contrasting to the present finding, [24] obtained higher (80 to 70\%) morphologically normal spermatozoa in Fancy breed cocks in Poland. Usually sperm abnormalities indicate disturbances of spermatogenesis and this could be attributed to age, nutrition and pollution [4]. Moreover, improper handling of ejaculates during processing may contribute to increased sperm abnormalities in semen. Nevertheless, the proportion of normal sperm morphology in the present study was good enough for routine $\mathrm{AI}$ in poultry.

\section{Conclusion}

It can be concluded that the semen parameters did not differ significantly among individual cocks of Sasso line. Sperm concentration varied significantly among individual cocks of Synthetic, White Rock and Assel RIR lines. Only the variations in ejaculate volume, sperm motility, sperm concentration and proportion of live spermatozoa among 4 different lines of cocks were significant $(\mathrm{P}<0.05)$.

\section{Acknowledgement}

The research was conducted at the Community-based Dairy Veterinary Foundation (CDVF) Laboratory, Department of Surgery and Obstetrics and the Poultry Farm, Bangladesh Agricultural University, Mymensingh.

\section{References}

[1] M. Hossain, Veterinary service in Bangladesh: More attention towards regulatory service, in BVA seminar on state veterinary services in Bangladesh (Present status and future perspective), 2012, 27-32.

[2] R.G. Saacke, Semen quality in relation to semen preservation, Journal of Dairy Science, 66,1983, $2635-2644$.

[3] K.K.H. Schneider, Effect of Strain and Spermatologic Protection on ejaculate, production and semen quality of young gander, World Poultry Journal, $8,1992,130-139$.

[4] G.S. Bah, S.U.R. Chaughari, J.D. Al-Amin,Semen characteristics of local breeder cocks in the Sahel region of Nigeria. Revued'elevageet de medecineveterinaire des pays tropicaux, 54, 2001, 153-158.

[5] P.B. Tuncer, H. Kinet, andN. Ozdogan,Evaluation of some spermatological characteristics in Gerze cocks,Ankara University Veterinary VeterinerFakultesiDergis,55, 2008, 99-102.

[6] S.O. Peters, O.D. Shoyebo, B.M. Ilori, M.O. Ozoje, C.O.N. Ikeobi andO.A. Adebambo,Semen quality traits of seven strain of chickens raised in humid tropics, International Journal of Poultry Science, 7, 2008, 949-953.

[7] S. Alkan, A. Baran, B.O. Ozdas, and M. Evecen,Morphological defects in turkey semen,TurkishJournalof Veterinary Animal Science,26, 2001, 1087-1092.

[8] P.R. Dumpala, H.M. Parker andC.D. McDaniel,The effect of semen storage temperature and diluent type on the sperm quality index of broiler breeder semen.International Journal of Poultry Science, 5, 2006, 838-845.

[9] Saeed and Al-Soudi, Semen quality traits of seven strains of chickens raised in the humid tropics, Journal of Animal and Veterinary Advances, 7, 1975, 848-849.

[10] C.N. Egbunike and J.A. Oluyemi, Comparative studies of the reproductive capacity of the Nigerian and Exotic poultry breeds, Nigerian Journal of Animal Production,6, 1979, 47- 51.

[11] S.K. Das, Evaluation of native cock semen and effects of diluents and preservation time on its characteristics.MS Thesis, Department of Surgery and Obstetrics, Faculty of Veterinary Science, Bangladesh Agricultural University, Mymensingh, 2010

[12] R.D. Martin, Artificial insemination of poultry.Poultry Essays, Essay 14, Bernal Publishing.www.bernalpublishing.com/poultry/essays/essay14.shtml

[13] G.E.vans andW.M.C. Maxwell,Salamon's artificial insemination of sheep and goats, Butterworths, Sydney, $1990,85-121$.

[14] J.L. Hancock, The morphology of boar spermatozoa, Jounal of RoyalMicroscopical Society,76, 1957, 84-97.

[15] J.P. Maule, The semen of animals and artificial insemination. Common Wealth Agricultural Bureaux England. 1962.

[16] G.C. Harris, J.A. Benson andR.S. Sellers, The influence of day length, body weight and age on the production ability of breeder cockerels, International Journal of Poultry Science,63, 1980, 1705-1710.

[17] G.O. Adeyemo, O.G. Longe and D.O. Adejumo, The reproductive performance of breeder cocks fed cottonseed cake-based diets, International Journal of Poultry Science, 6, 2007, 140-144.

[18] P.B. Tuncer, H. Kinet andN. Ozdogan,Evaluation of some spermatological characteristics in Gerze cocks. Ankara University Veterinary VeterinerFakultesiDergisi,55, 2008, 99-102. 
[19] T. Chalah, F. Seigneurin, E. Blesbois andJ.P. Brillard,In vitro comparison of fowl sperm viability in ejaculates frozen by three different techniques and relationship with subsequent fertility in vivo, Cryobiology39,1999, 185-191.

[20] T.M.B. Mosenene,Characterijation and cryopreservation of semen of four South African chicken breeds. MSc, Faculty of Natural and Agricultural Science, Department of Animal, Wildlife and Grassland Science, University of Free State Bloemfontein, 2009.

[21] H.M. Parker andC.D. McDaniel,The immediate impact of semen diluent and rate of dilution on the sperm quality index, ATP utilization, gas exchange and ionic balance of broiler breeder sperm,International Journal of Poultry Science, 85, 2006, 106-116.

[22] E. Podgorny, S. Weeyk andA. Lada-Gorzowska, Variations in cock sperm quality throughout the year, congress animal reproduction artificial insemination, 1976,1057-1060.

[23] A. Chalov,Semen quality and fertilizing capacity of cocks, Ptiferodstron20,1970, 24-26.

[24] A.Siudzinska and E. Lukaszewicz, The effect of breed on freezability of semen of fency fowl, Journal of animal science, 26, 2008, 331-340.

[25] S. Tabatabaei, R.A. Batavani andA.R. Talebi,Comparism of semen quality in indigenous and ross broiler breeder roosters,Journal of Animal and Veterinary Advances,8, 2009, 90-93.

[26] K. Tselutin, F. Seigneurin andE. Blesbois, Comparison of cryoprotectents and methods of cryopreservation of fowl spermatozoa,Poultry science, 78,1999, 586-590. 